\title{
ANALISA DAN PERANCANGAN SISTEM INFORMASI PENGISIAN FRS ONLINE BERBASIS WEB PADA STMIK ROSMA KARAWANG
}

\author{
Ethika Rosanti $^{1 *}$, Dudi Awalludin ${ }^{2}$, Yeny Rostiani ${ }^{3}$ \\ ${ }^{1}$ Ethika Rosanti: ${ }^{1}$ STMIK Rosma \\ ${ }^{2}$ Dudi Awalludin: ${ }^{2}$ STMIK Rosma \\ ${ }^{3}$ Yeny Rostiani: ${ }^{3}$ STMIK Rosma \\ Email: dudi@rosma.ac.id, yeny@rosma.ac.id
}

\begin{abstract}
The aim of research in Karawang Rosma STMIK are renewing charging system FRS by students who still use manual way into the charging information system Web-based Online FRS uses PHP and MySQL as the database. Methods used by the author of a method of waterfall which is made up of several phase which is analysis on key aspects of need (data collection), design ( the making of a system design proposals ), coding / the writing of a program code and application of testing program (integration \& amp; testing) this stage it can be said the final in the making of a system After doing the analysis, the design and encoding then the system can be used by the user. Results of the study authors found that the process of filling FRS still perform manual system is to fill the sheet charging FRS which at times can be damaged or lost. Sometimes there are students who slow down the collection of FRS with a wide variety of reasons. In addition, students are too dependent on the Kaprodi for manual charging FRS requires guidance and Lecturer in question does not at any time be able to implement the guidance for teaching schedule or the like. This makes the process of filling the FRS becomes too late. The conclusion of this study, namely through php based programming is expected to solve the problem in the previous system was not computerized well. It is hoped the system can be accessed anytime and anywhere. This helping the various parties, both students in the collection of FRS timely and BAAK part in processing the data subjects to determine the schedule of lectures.
\end{abstract}

Keywords: FRS, SKS, IPK, PHP, MySQL and Waterfall. Abstrak

Tujuan penelitian pada STMIK Rosma Karawang ini adalah memperbaharui sistem pengisian FRS oleh mahasiswa yang masih menggunakan cara manual menjadi sistem informasi pengisian FRS Online berbasis Web menggunakan PHP dan MySQL sebagai Database. Metode yang digunakan oleh penulis yaitu metode waterfall terdiri dari beberapa fase yaitu analisa terhadap kebutuhan (pengumpulan data), perancangan (pembuatan desain sistem usulan), Coding/penulisan kode program dan Penerapan/pengujian program (Integration \& Testing) tahapan ini bisa dikatakan final dalam pembuatan sebuah sistem. Setelah melakukan analisa, desain dan pengkodean maka sistem dapat digunakan oleh User. Hasil penelitian penulis menemukan bahwa proses pengisian FRS masih melakukan sistem secara manual yaitu dengan mengisi lembar pengisian FRS yang sewaktu-waktu dapat rusak atau hilang. Terkadang ada mahasiswa yang memperlambat pengumpulan FRS dengan berbagai macam alasan. Selain itu, mahasiswa terlalu bergantung dengan Kaprodi karena pengisian FRS manual memerlukan bimbingan dan Dosen yang bersangkutan tidak sewaktu-waktu dapat melaksanakan bimbingan karena jadwal mengajar atau sebagainya. Hal ini membuat proses pengisian FRS menjadi terlambat. Kesimpulan dari penelitian ini, yaitu melalui pemograman berbasis php ini diharapkan dapat memecahkan masalah pada sistem terdahulu yang tidak terkomputerisasi dengan baik. Diharapkan sistem ini dapat diakses kapan dan dimana saja. Sehingga membantu berbagai pihak, baik mahasiswa dalam pengumpulan FRS tepat waktu dan bagian BAAK dalam memproses data mata kuliah untuk menentukan jadwal perkuliahan.

Kata Kunci: FRS, SKS, IPK, PHP, MySQL dan Waterfall.

Article history:

Accepted 3, November 2020 


\section{Corresponding Author:}

Nama Penulis, Dudi Awaludin.

Departemen, STMIK Rosma

Intansti, STMIK Rosma

Alamat, Jl. Kertabumi No.62 Karawang Barat 41311 Karawang, Jawa Barat.

Email, dudi@rosma.ac.id

\section{Pendahuluan}

Dengan mulai berkembangnya dunia teknologi, komputer bukan hanya sekedar pengolah data dan gambar saja tetapi penggunaanya semakin meluas menjadi salah satu sarana komunikasi, media informasi, dan edukasi. Perkembangan teknologi informasi yang saat ini berkembang dengan pesatnya yaitu dengan menggunakan internet, maka informasiinformasi yang diperlukan dapat diperoleh dengan mudah. Komunikasi juga semakin mudah dilakukan melalui internet. Teknologi internet bukan lagi menjadi kalimat yang asing bagi orang yang berkecimpung di dunia komputer. Bahkan bagi orang awam sekalipun kata-kata world wide web (WWW) seakan-akan sudah menjadi bagian yang tak terpisahkan bagi kehidupan manusia yang modern saat ini.

Website adalah salah satu revolusi di bidang informasi berbasis teknologi internet. Semua kalangan mengetahui keunggulan Website yaitu dapat dijadikan alternatif bagi pengembangan sistem informasi dengan biaya yang rendah. Kemudahan-kemudahan yang dihasilkan oleh jaringan internet ini telah pula membuat proses perkuliahan dapat dipermudah dalam beberapa aspek, salah satunya proses pengisian Formulir Rencana Studi (FRS).

Dalam dunia pendidikan, proses pengisian Formulir Rencana Studi adalah kegiatan rutin yang selalu dilakukan di awal semester. Seperti Universitas atau Sekolah Tinggi pada umumnya, setiap awal semester diperlukannya pengisian Formulir Rencana Studi (FRS) sebagai bukti kontrak perkuliahan selama kegiatan mengajar berlangsung. STMIK Rosma merupakan salah satu Sekolah Tinggi yang sistem pengisian FRS oleh mahasiswa masih menggunakan cara manual. Pertama, mahasiswa harus melakukan pembayaran kuliah dengan lunas dan menerima FRS yang telah dibubuhi tandatangan oleh bagian administrsi. Kedua, mahasiswa mengisi FRS secara manual sesuai dengan daftar mata kuliah wajib. Ketiga, mahasiswa melakukan bimbingan dalam pengisian FRS dengan Dosen Kaprodi (Kepala Program Studi) untuk membahas mata kuliah yang wajib berdasarkan nilai IPK (Indeks Prestasi Kumulatif).

Jika, Dosen Kaprodi menyetujui mata kuliah yang wajib diambil mahasiswa bersangkutan, maka Dosen Kaprodi akan memberikan tanda tangan. Mahasiswa juga harus meminta tanda tangan ke Penasihat Akademik untuk validasi akhir pengisian FRS. Hal ini dinilai kurang efisien, karena memperbesar resiko hilang atau rusaknya lembar FRS, antrian panjang ketika akan melakukan bimbingan, atau sifat buruk mahasiswa yang selalu menunda pengisian FRS sampai melebihi batas waktu yang ditentukan.

Penelitian terdahulu tentang Sistem Informasi Pengisian FRS secara Online adalah sebagai berikut: Pertama S. Karouw, dkk membahas tentang rekayasa ulang proses bisnis registrasi pengisian KRS Online di Portal Akademik UNSRAT dengan menggunakan metode BPR (Business Process Reengineering). Proses bisnis pengisian KRS Online Portal Akademik diawali dengan identifikasi aktivitas dan dilanjutkan dengan membuat model proses bisnis menggunakan Business Process Notation Model (BPMN)[1], Kedua R. Syafitra membahas 
tentang pengembangan sistem menggunakan bahasa pemograman Java dan PHP, dimana Java digunakan untuk membangun aplikasi Android dan PHP digunakan untuk membangun aplikasi Web. Sedangkan basis data yang digunakan adalah MySQL. Metodologi pengembangan sistem penulis gunakan adalah metodologi Waterfall[2], pada yang Ketiga Anak Agung Gde Putra Ajiwerdi, Dkk mengembangkan sebuah aplikasi yang dapat membantu mahasiswa dalam memilih matakuliah saat pengisian KRS. menggunkan sistem pendukung keputusan (SPK). SPK ini merupakan sistem yang dapat membantu mahasiswa mengambil keputusan dengan melengkapi mahasiswa dengan informasi mengenai matakuliah yang disarankan dan tidak disarankan untuk diambil saat pengisian KRS. Sehingga sistem ini tidak dimaksudkan untuk menggantikan mahasiswa dalam pengambilan keputusan. Sedangkan model yang digunakan dalam SPK ini adalah Fuzzy Multi-Atribute Decision Making (FMADM) dengan metode Simple Additive Weighting (SAW)[3].

Atas dasar permasalahan yang telah di utarakan penulis diatas maka penulis mencoba mengungkapkan objek skripsi dengan judul "Analisa dan Perancangan Pengisian FRS Online Berbasis Web pada STMIK Rosma Karawang“"

\section{Tinjauan Pustaka}

Teori umum terdiri dari konsepkonsep atau definisi mengenai gambaran umum yang berkaitan dengan objek dari judul penelitian "Analisa dan Perancangan Sistem Informasi Pengisian FRS Online berbasis Web"

a. Sistem Informasi

Menurut Indrajani $(2011,48)$ dalam bukunya Perancangan Basis Data All in 1 Sistem adalah beberapa elemen yang terintegrasi untuk mencapai tujuan dari perusahaan atau organisasi yang terdiri dari beberapa sumber daya dimana sumber daya tersebut bekerja untuk mencapai tujuan perusahaan atau organisasi tersebut[4]. Sistem adalah suatu kumpulan atau himpunan dari unsur, komponen, atau variabel yang terorganisasi, saling berinteraksi, saling bergantung satu sama lain dan terpadu[5]. Sedangkan informasi adalah data yang diolah menjadi bentuk yang lebih berguna dan berarti bagi penggunanya[6]. Berdasarkan pengertian sistem dan informasi diatas disimpulkan bahwa sistem informasi adalah suatu kumpulan prosedur/sub sistem yang saling berhubungan pada aktifitas manajerial untuk mencapai suatu tujuan organisasi dengan menggunkan teknologi informasi dalam pengolahannya, yang dapat informasi tersebut bias dimanfaatkan oleh pihak internal dan eksternal.[4]

b. Analisis Sistem

Analisis Sistem adalah suatu teknik pemecahan masalah yang mengurai sistem menjadi potongan-potongan komponen untuk tujuan mempelajari seberapa baik bagian•bagian komponen bekerja dan berinteraksi untuk mencapai tujuan mereka.[7]. Sedangkan menurut Stair dan Reynold, Analisis Sistem adalah fase pengembangan sistem yang menentukan sistem informasi apa yang harus dilakukan untuk memecahkan masalah yang sudah ada dengan mempelajari sistem dan proses kerja untuk mengidentifikasi kekuatan, kelemahan dan peluang untuk perbaikan[8].

c. Pengertian Perancangan Sistem

Perancangan Sistem adalah teknik pemecahan masalah komplementer (untuk analisis sistem) yang mengumpulkan kembali potongan komponen sistem ke dalam sistem yang lengkap yang sudah ditingkatkan. Ini mungkin melibatkan menambahkan, menghapus, dan mengubah potongan relatif terhadap sistem yang asli[7]. Menurut Stair dan Reynolds, 
$\begin{array}{lcr}\text { Perancangan } & \text { Sistem adalah } & \text { fase } \\ \text { pengembangan } & \text { sistem } & \text { yang }\end{array}$ mendefinisikan bagaimana system informasi akan melakukan apa yang harus dilakukan untuk mendapatkan solusi masalah[8].

Pada bagian ini akan membahas mengenai teori-teori khusus yang berkaitan dengan prosedur pengisian FRS dan pengelolaan mata kuliah berdasarkan syarat dan ketentuan yang ada sehingga menghasilkan IPS (Indeks Preastasi Semester) dan IPK (Indeks Prestasi Kumulatif). Teori tersebut dikutip berdasarkan buku BPM STMIK Rosma Karawang[9].

a. FRS (Formulir Rencana Studi). Berisi daftar mata kuliah yang ditempuh oleh mahasiswa dalam semester yang bersangkutan dan beberapa hal yang berkaitan. FRS diperoleh dari bagian administrasi keuangan tiap awal semester. FRS diisi oleh mahasiswa dengan persetujuan PA.

b. SKS (Sistem Kredit Semester). Pelayanan yang diberikan kepada mahasiswa dalam memenuhi program pendidikan yang dibebankan pada studi mahasiswa dengan menggunakan Sistem Kredit Semester (SKS) yaitu cara penyelanggaraan pendidikan dengan menentukan beban studi mahasiswa dalam jumlah satuan kredit dan menggunakan semester sebagai unit pelaksanaan program pendidikan.

c. Daftar Hadir Mahasiswa. Berisi daftar data mahasiswa berupa Nama, NIM, Mata kuliah, Tahun Angkatan, dan lain-lain. Daftar Hadir Mahasiswa harus ditandatangani oleh mahasiswa serta diketahui oleh dosen bersangkutan setiap akhir kuliah.

d. KHS (Kartu Hasil Studi). Berisi huruf mutu dari mata kuliah pada semester yang bersangkutan yang telah diperoleh mahasiswa. KHS ini dapat digunakan PA (Pembimbing

Akademik) pada waktu mengisi FRS.

e. IPK (Indeks Prestasi Kumulatif). Angka yang menunjukan prestasi mulai dari semester pertama sampai dengan semester terakhir yang telah ditempuh secara kumulatif.

f. Transkrip Nilai. Berisi huruf mutu dari seluruh mata kuliah yang ditempuh dari semester I sampai dengan semester VIII untuk strata satu dan semester I sampai dengan VI untuk diploma tiga. Transkrip nilai yang disahkan oleh ketua STMIK sebagai batas akhir dari semua beban studi yang ditawarkan (menurut ketentuan).

STMIK Berdasarkan Peraturan

Perundangan Pemerintah Republik Indonesia Nomor 4 tahun 2014 mengenai Penyelenggaraan Pendidikan Tinggi dan Pengelolaan Perguruan Tinggi pasal 1 ayat 9 menyatakan: "Sekolah Tinggi adalah Perguruan Tinggi yang menyelenggarakan pendidikan akademik dan dapat menyelenggarakan pendidikan vokasi dalam satu rumpun ilmu pengetahuan dan/atau teknologi tertentu dan jika memenuhi syarat, Sekolah Tinggi dapat menyelenggarakan pendidikan profesi." [10]

\section{Metode}

Metode penelitian yang digunakan dalam penelitian ini adalah metode Waterfall yang terdiri dari beberapa tahap: analisis kebutuhan, perancangan, Coding, Implementasi dan Pengujian. Pada penelitian ini hanya mengambil tahap Analisis Kebutuhan dan Perancangan dengan menggunakan Flow of Document, Data Flow Diagram, Entitas Relationship Diagram, dan Rancangan Tabel Database.

\section{Hasil Penelitian dan Pembahasan}

Sekolah Tinggi Manajemen Informatika dan Komputer (STMIK) Rosma memilik 2 jenjang Strata Satu (S1) 
yaitu Teknik Informatika dan Sistem Informasi dan Jenjang Diploma Tiga (D3) yaitu Manajemen Informatika dan Komputerisasi Akuntansi.

STMIK Rosma dalam pelayanan terhadap mahasiswa dibidang Akademik salah satunya adalah pelayanan dalam hal pengisian Formulir Rencana Studi (FRS) yang diselenggarakan setiap semesternya. FRS yang harus diisi oleh mahasiswa memiliki 3 rangkap yaitu sesuai warna rangkap. Warna kuning untuk bagian keuangan dan warna putih untuk BAAK. Sedangkan warna pink disimpan oleh mahasiswa itu sendiri.

Adapun syarat dan ketentuan yang harus dijalankan oleh mahasiswa di STMIK Rosma Karawang dalam pengisian FRS.

1. Mahasiswa harus membawa bukti pembayaran dari bagian keuangan

2. Mahasiswa harus membawa KHS yang berisi nilai IPK dari semester sebelumnya.

3. Pengisian mata kuliah berdasarkan nilai IPK masing-masing mahasiwa, sehingga mahasiswa dengan IPK kurang dari standar dapat mengulang mata kuliah yang bersangkutan dengan maksimum 24 SKS ketentuan pengambilan SKS seperti pada Tabel 1.

Tabel 1 Beban Studi Berdasarkan IPk

\begin{tabular}{|l|l|}
\hline IPK & $\begin{array}{l}\text { SKS yang boleh } \\
\text { diambil }\end{array}$ \\
\hline $3,00-4,00$ & $21-24$ \\
\hline $2,50-2,99$ & $18-21$ \\
\hline $2,00-2,49$ & $15-18$ \\
\hline $1,50-1,99$ & $12-15$ \\
\hline $0,99-1,49$ & $0-12$ \\
\hline
\end{tabular}

1. Mahasiswa harus melakukan pembayaran Registrasi dan BPP untuk semester yang pertama di bagian administrasi keuangan.

2. Mahasiswa menerima bukti pembayaran dan lembar FRS rangkap 3 yang telah ditandatangani oleh bagian keuangan.

3. Mahasiswa melakukan pengisian mata kuliah sesuai dengan distribusi mata kuliah yang telah disediakan untuk semester pertama kemudian mahasiswa memberikan tandatangan pada kolom yang disediakan.

4. Mahasiswa menghadap PA untuk meminta validasi tentang mata kuliah paket disemester satu.

5. Mahasiswa menghadap Kaprodi untuk meminta validasi tentang mata kuliah yang dibebankan dan telah disetujui PA. Kemudian memberikan tandatangan pada kolom yang disediakan.

6. Mahasiswa mengumpulkan FRS rangkap 3 tersebut dengan pembagian sesuai warna rangkap. Warna kuning untuk bagian keuangan dan warna putih untuk BAAK. Sedangkan warna pink disimpan oleh mahasiswa itusendiri.

\section{A. Prosedur pengisan FRS}

Jurnal Interkom: Jurnal Publikasi Ilmiah Bidang Teknologi Informasi dan Komunikasi

Volume 15 Nomor 03 Bulan Oktober - Tahun 2020 


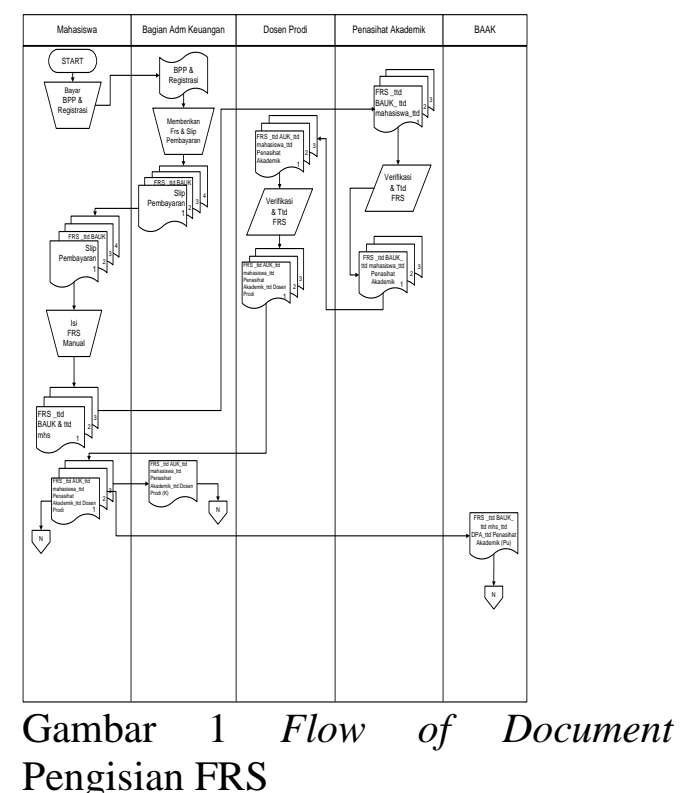

Pengisian FRS

\section{B. Prosedur pengisian FRS berdasarkan IPK}

1. Mahasiswa harus melakukan pembayaran Registrasi dan BPP untuk semester yang akan sisstem di bagian administrasi keuangan.

2. Mahasiswa menerima bukti pembayaran (Slip) dan lembar FRS rangkap 3 yang telah ditandatangani oleh bagian keuangan.

3. Mahasiswa menerima KHS dari BAAK untuk melihat IPK terakhir yang diperoleh.

4. Mahasiswa melakukan pengisian mata kuliah sesuai dengan distribusi mata kuliah yang telah disediakan untuk semester yang akan sisstem kemudian mahasiswa memberikan tandatangan pada kolom yang disediakan.

5. Mahasiswa melakukan bimbingan dengan Kaprodi dan Penasihat Akademik (PA) untuk mengesahkan mata kuliah yang akan dibebankan pada mahasiswa bersangkutan berdasarkan nilai IPK disemester sebelumnya.

6. Apabila nilai mahasiswa mencukupi untuk standar pengambilan mata kuliah maka PA akan memberikan tandatangan pada kolom yang disediakan.

7. Mahasiswa menghadap Kaprodi untuk meminta validasi tentang mata kuliah yang dibebankan dan telah disetujui PA sebelumnya. Kaprodi memberikan saran berdasarkan kebutuhan mahasiswa. Kemudian memberikan tandatangan pada kolom yang disediakan.

8. Mahasiswa mengumpulan FRS rangkap 3 tersebut dengan pembagian sesuai warna rangkap. Warna kuning untuk bagian keuangan dan warna putih untuk BAAK. Sedangkan warna pink disimpan oleh mahasiswa itu sendiri.

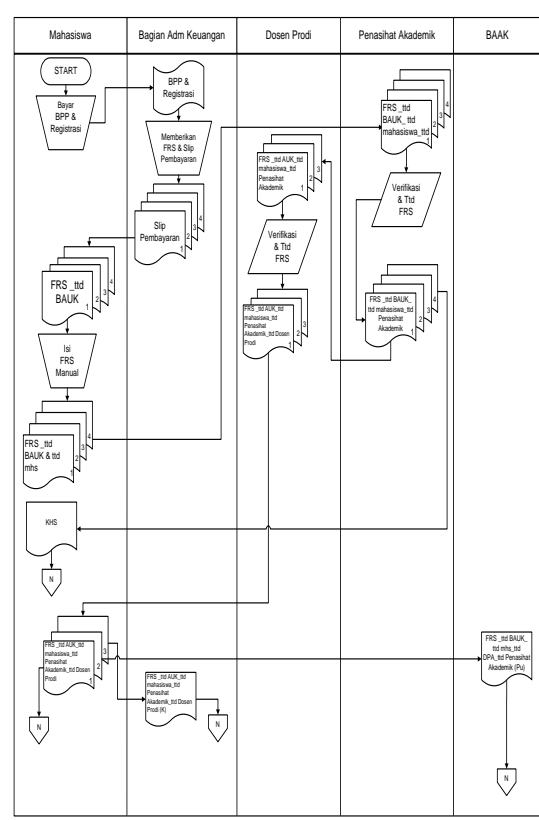

Gambar 2 Flow of Document Pengisian FRS berdasarkan IPK.

\section{Identifikasi Permasalahan}

Proses pengisian FRS masih melakukan sistem secara manual yaitu dengan mengisi lembar pengisian FRS yang sewaktu-waktu dapat rusak atau hilang. Terkadang ada mahasiswa yang memperlambat pengumpulan FRS dengan berbagai macam Sisstems. Selain itu, mahasiswa terlalu bergantung dengan Kaprodi karena pengisian FRS manual 
memerlukan bimbingan dan Dosen yang bersangkutan tidak sewaktu-waktu dapat melaksanakan bimbingan karena jadwal mengajar atau sebagainya. Hal ini membuat proses pengisian FRS menjadi terlambat.

Untuk memecahkan masalah tersebut akan dibuat sistem pengisian FRS secara online berbasis web. Sistem ini dapat diakses kapan dan dimana saja. Sehingga membantu berbagai pihak, baik mahasiswa dalam pengumpulan FRS tepat waktu dan bagian BAAK dalam memproses data mata kuliah untuk menentukan jadwal perkuliahan.

\section{Rancangan Sistem Yang Diusulkan}

Sesuai dengan permasalahan yang ada, maka penulis mengusulkan untuk membangun sebuah Sistem baru yang berbasis web. Pengolahan data yang mencakup data mahasiswa, mata kuliah, dan nilai IPK sudah di input pada sebuah program dan disimpan dalam database.

1. Prosedur Prosedur Sistem Informasi Pengisian FRS Online

a. Bagian Administrasi menerima data mahasiswa yang telah membayar BPP dan Registrasi

b. Bagian Administrasi merubah status pembayaran mahasiswa bersangkutan.

c. Mahasiswa Login ystem dengan Userid dan Password yang sudah terdaftar.

d. Mahasiswa mengisi FRS sesuai dengan mata kuliah yang disediakan disemester yang akan ystem

e. Penasihat Akademik memeriksa pengajuan FRS Online dari mahasiswa.

f. FRS yang telah di verifikasi oleh PA kemudian dilanjutkan ke Kaprodi untuk diverifikasi lanjut.

g. FRS tersimpan di database, mahasiswa dapat mencetaknya

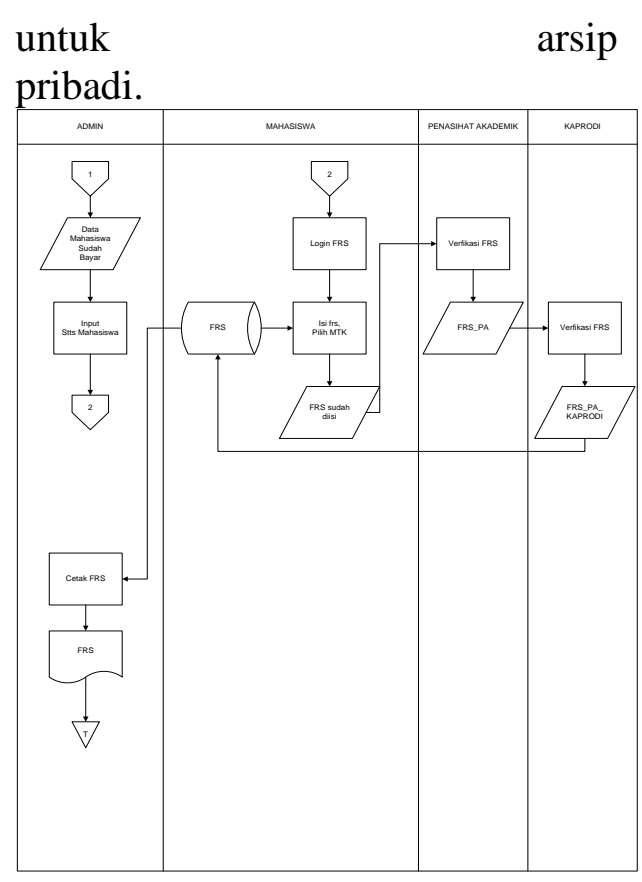

Gambar 3 Flow of Document Prosedur Pengisian FRS Online yang Baru

2. Prosedur Pengisian FRS berdasrkan IPK:

a. Bagian Administrasi menerima data mahasiswa yang telah membayar BPP dan Registrasi

b. Bagian Administrasi merubah status pembayaran mahasiswa bersangkutan.

c. Mahasiswa Login ystem dengan Userid dan Password yang sudah terdaftar.

d. Mahasiswa mengisi FRS sesuai dengan mata kuliah yang disediakan disemester yang akan ystem dengan pedoman KHS yang tersedia. Admin akan menginput mata kuliah tambahan jika terdapat nilai mata kuliah yang kurang (C/D/E) atau nilai IPK diatas 3,00 dan maksimum SKS < 24. Mahasiswa dapat mengajukan mata kuliah tersebut dalam pengisian FRS berjalan.

e. Penasihat Akademik memeriksa pengajuan FRS Online dari 
mahasiswa berdasarkan KHS untuk melihat IPK mahasiswa.

f. FRS yang telah di verifikasi oleh PA kemudian dilanjutkan ke Kaprodi untuk diverifikasi lanjut.

g. FRS tersimpan di database, mahasiswa dapat mencetaknya untuk arsip pribadi.

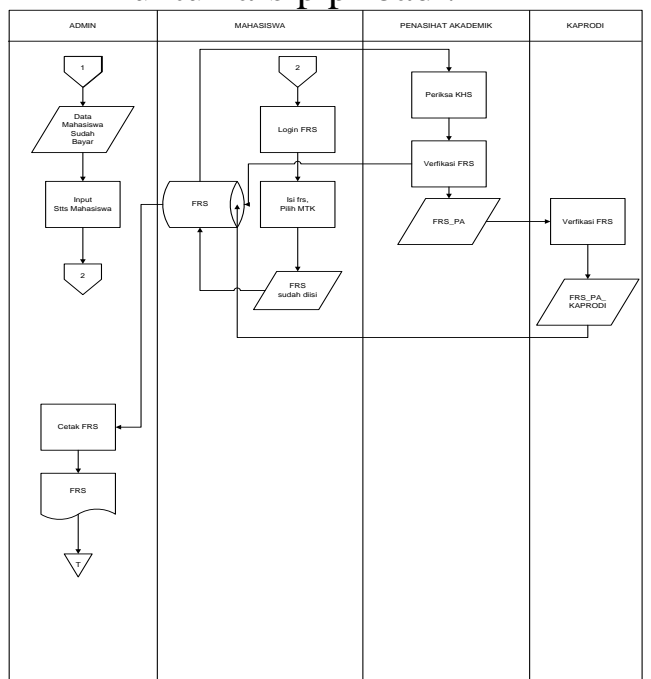

Gambar 4 Flow of Document Prosedur Pengisian FRS Online berdasarkan IPK yang baru

Setelah melihat Rancangan dari Prosedur pengisian FRS yang baru yang terlihat pada Gambar 3 dan Gambar 4, yang nantinya menjadi acuan dalam perancangan Data Flow Diagram ystem usulan pengisian FRS Online pada STMIK Rosma Karawang:

1. Diagram Konteks

Diagram kontek merupakan penggambaran system secara umum seperti pada gambar 5 dibawah ini:

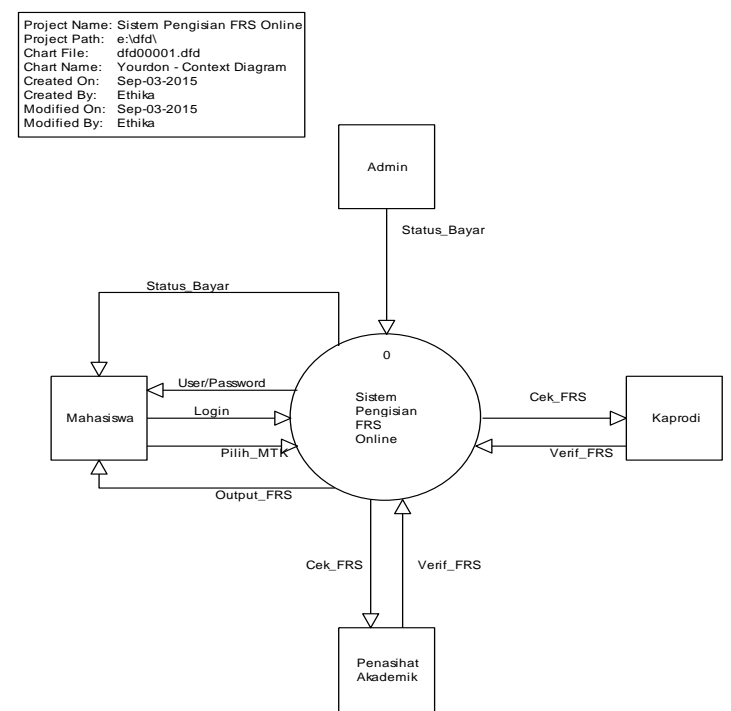

Gambar 5 Diagram Konteks Sistem Pengisian FRS Online

\section{Data Flow Diagram (DFD) Level 0}

DFD merupakan penggambaran sistem supaya kita bias melihat sistem lebih detail dari Diagram konteks seperti terlihat pada gambar 6 .

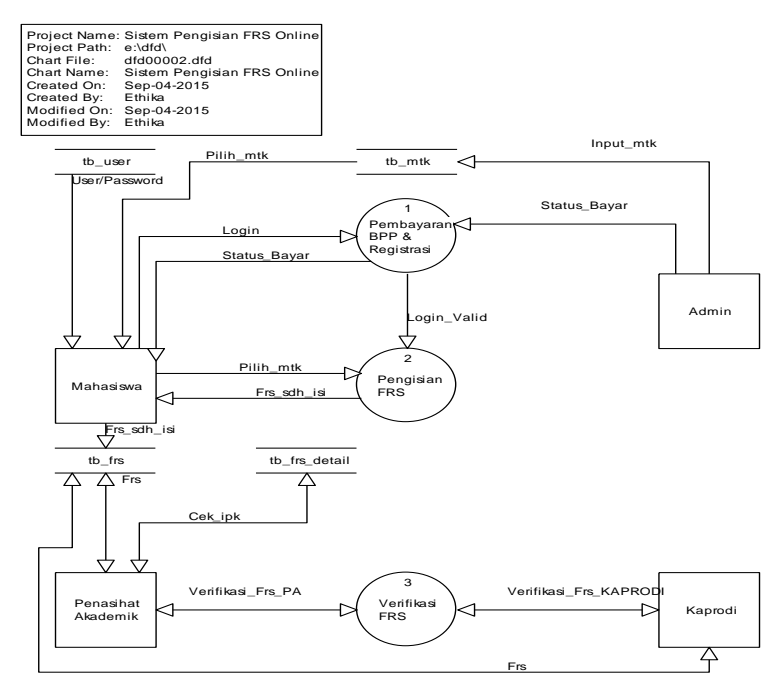

Gambar 6 DFD Level 0 Sistem Informasi Pengisian FRS Online

\section{Entitas Relationship Diagram (ERD)} ERD merupakan dasar dalam perancangan database dimana pernggambarannya berdasarkan DFD Level 0 (gambar 6). ERD bisa anda lihat seperti pada gambar 7 


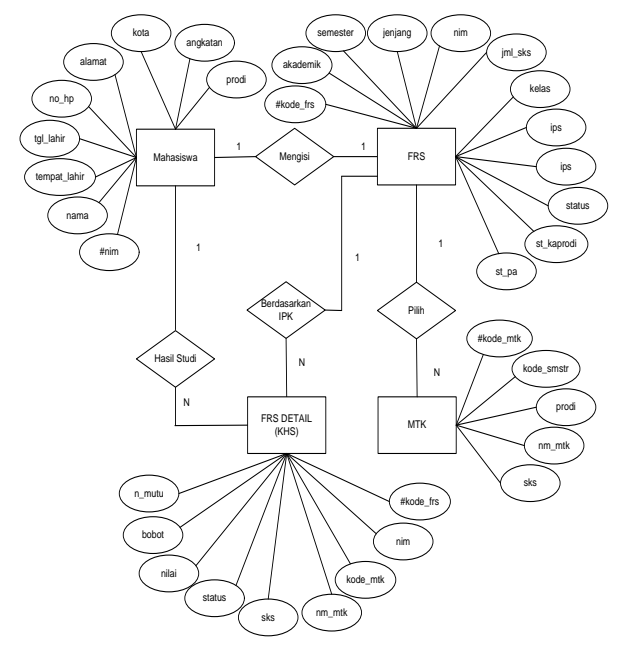

Gambar 7 ERD

4. Rancangan Tabel pada Database Perancangan Databse dibuat berdasarkan hasil ERD yang dibuat berdasarkan entitas pada ERD kemudian dijasikan rancangan Tabel. Rancangan Tabel yang dihasilkan mencapai 5 tabel terdiri dari: (Tabel 2 sampai Tabel 8)

a. Rancangan Tabel FRS Header

Nama tabel: T_FRSH

Fungsi : Menyimpan data frs

Media : Harddisk

Tabel 2 Rancangan Tabel FRS Header

\begin{tabular}{|l|l|l|l|l|}
\hline No & Nama Field & Type & Size & Key \\
\hline 1 & kode_frs & Varchar & 10 & P \\
\hline 2 & Akademik & Varchar & 10 & \\
\hline 3 & Semester & Varchar & 10 & \\
\hline 4 & Jenjang & Varchar & 15 & \\
\hline 5 & Nim & Varchar & 12 & \\
\hline 6 & jml_sks & Integer & 4 & \\
\hline 7 & Kelas & Varchar & 10 & \\
\hline 8 & Ips & Float & & \\
\hline 9 & Ipk & Float & & \\
\hline 10 & Status & Varchar & 1 & \\
\hline 11 & st_kaprodi & Varchar & 10 & \\
\hline
\end{tabular}

\begin{tabular}{|l|l|l|l|l|}
\hline 12 & st_pa & Varchar & 10 & \\
\hline
\end{tabular}

b. Rancangan Tabel FRS Detail Nama tabel : T_FRSD

Fungsi : Menyimpan data frs yang telah diverifikasi

Media : Harddisk

Tabel 3 Rancangan Tabel FRS Detail

\begin{tabular}{|l|l|l|l|l|}
\hline No & Nama Field & Type & Size & Key \\
\hline 1 & kode_frs & Varchar & 15 & F \\
\hline 2 & nim & Varchar & 12 & F \\
\hline 3 & kode_mtk & Varchar & 12 & F \\
\hline 4 & status & Varchar & 1 & \\
\hline 5 & Nilai & Varchar & 2 & \\
\hline 6 & Bobot & Integer & 2 & \\
\hline 7 & n_mutu & Integer & 2 & \\
\hline
\end{tabular}

c. Rancangan Tabel Program Studi (Prodi)

Nama tabel: T_Prodi

Fungsi : Menyimpan data program studi yang ada

Media : Harddisk

Tabel 4 Rancangan Tabel Program Studi (Prodi)

\begin{tabular}{|l|l|l|l|l|}
\hline No & Nama Field & Type & Size & Key \\
\hline 1 & Kd_Prodi & Varchar & 10 & $\mathrm{P}$ \\
\hline 2 & nm_Prodi & Varchar & 35 & \\
\hline 3 & Jenjang & Varchar & 2 & \\
\hline
\end{tabular}

d. Rancangan Tabel Mahasiswa

Nama tabel : T_Mhs

Fungsi : Menyimpan biodat mahasiswa

Media : Harddisk 


\section{Tabel 5 Rancangan Tabel Biodata}

Mahasiswa

\begin{tabular}{|l|l|l|l|l|}
\hline No & Nama Field & Type & Size & Key \\
\hline 1 & Nim & Varchar & 12 & P \\
\hline 2 & Nama & Varchar & 35 & \\
\hline 3 & tempat_lahir & Varchar & 35 & \\
\hline 4 & tgl_lahir & Date & & \\
\hline 5 & no_hp & Varchar & 12 & \\
\hline 6 & Alamat & Varchar & 100 & \\
\hline 7 & Kota & Varchar & 35 & \\
\hline 8 & Angkatan & Varchar & 10 & \\
\hline 9 & Prodi & Varchar & 35 & \\
\hline
\end{tabular}

e. Rancangan Tabel Mata Kuliah

Nama tabel: T_MatKul

Fungsi : Menyimpan data mata

kuliah tiap semester

Media : Harddisk

Tabel 6 Rancangan Tabel Mata Kuliah

\begin{tabular}{|l|l|l|l|l|}
\hline No & Nama Field & Type & Size & Key \\
\hline 1 & kode_mtk & Varchar & 10 & P \\
\hline 2 & smstr & Varchar & 10 & \\
\hline 3 & Prodi & Varchar & 35 & \\
\hline 4 & nm_mtk & Varchar & 45 & \\
\hline 5 & Sks & Integer & 2 & \\
\hline
\end{tabular}

E. Kesimpulan Dan Saran

1. Kesimpulan

Berdasarkan hasil penelitian, pembahasan dan analisis yang telah dilakukan maka dapat diambil beberapa kesimpulan yaitu, antara lain:

a. Sistem ini dapat membantu melakukan proses bimbingan akademik antara mahasiswa dengan dosen PA dan Kaprodi secara online.

b. Dapat menghemat waktu dan biaya yang dikeluarkan ketika melakukan bimbingan akademik.

c. Poses pengisian FRS dapat digunakan dengan mudah. Dengan tampilan yang sederhana dan proses yang mudah dimengerti, mahasiswa dapat menggunakan program FRS Online tanpa menemukan kendala.

2. Saran

Sistem ini masih terdapat banyak kekurangan sehingga untuk pengembangan lebih lanjut disarankan agar:

a. Diharapkan sistem informasi ini dapat diterapkan dan juga dikembangkan sesuai dengan kebutuhan yang ada di STMIK Rosma Karawang

b. Melakukan pembaharuan data secara berkala untuk menjaga agar website tetap up-to-date.

c. Memberi tambahan menu sehingga mahasiswa nantinya tidak hanya dapat mengisi FRS dan melihat KHS tapi dapat melihat jadwal, kalender akademik dan sebagainya.

\section{DAFTAR PUSTAKA}

[1] S. Karouw, R. Tanggo, and S. C. Riady, "REKAYASA ULANG PROSES BISNIS REGISTRASI PENGISIAN KRS ONLINE PORTAL AKADEMIK UNIVERSITAS SAM RATULANGI," J. Tek. Inform., 2013 , doi: 10.35793/jti.3.1.2014.3926.

[2] R. Syafitra, "Rancang Bangun Aplikasi Bimbingan Akademik Berbasis Web dan Android pada Program Studi Manajemen S1 STIE MDP," Tek. Inform., 2013.

[3] D. Anak Agung Gde Putra Ajiwerdi, 
"Pengembangan Sistem Pendukung Keputusan Berbasis Mobile untuk pengisian Kartu Rencana Studi dengan Fuzzy Multi-Attribute Decision Making (FMADM) Metode Simple Additive Weighting (SAW)," Informatika, 2012.

[4] A. Solihin and D. Awalludin, "Analisis Dan Perancangan Sistem Informasi Inventory Control Berbasis Vb.Net Pada PT. Bekaert Indonesia," Techno Xplore J. Ilmu Komput. dan Teknol. Inf., 2019, doi: 10.36805/technoxplore.v4i2.827.

[5] T. Sutabri, Analisis Sistem Informasi. Yogyakarta, 2012.

[6] Jeperson Hutahean, "Konsep Sistem Informasi - Jeperson Hutahaean Google Buku," Deepublish. Deepublish, Yogyakarta, 2015.

[7] J. L. Whitten, L. D. Bentley, and K. C. Dittman, "Metode Desain dan Analisis Sistem," Yogyakarta Andi, 2015.

[8] R. Stair et al., "Principles of information systems," System, 2012.

[9] P. S. Rosma, Buku Panduan Mahasiswa, Pertama. Karawang: STMIK Rosma Karawang, 2010.

[10] P. RI, "PP 4 Tahun 2014," Penyelenggaraan Pendidik. Tinggi Dan Pengelolaan Perguru. Tingg, 2014. 